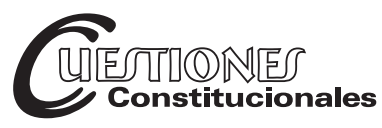

Revista Mexicana de Derecho Constitucional

Núm. 39, julio-diciembre 2018

\title{
El principio constitucional de eficiencia administrativa: contenido normativo y consecuencias jurídicas de su violación
}

\author{
The Constitutional Principle of Administrative \\ Efficiency: Normative Content and Legal \\ Consequences of its Violation
}

\begin{abstract}
Resumen: El artículo analiza el principio de eficiencia administrativa en la Constitución brasileña por la Enmienda Constitucional núm. 19/1998, defendiendo una interpretación sistemática de su contenido de conformidad con la cláusula del Estado social y democrático de derecho. Propone identificar los diversos desdoblamientos del contenido normativo del principio constitucional de eficiencia, apuntando a los principales deberes específicos impuestos a la administración pública. Al final, examina las consecuencias jurídicas objetivas generadas por el incumplimiento del principio de eficiencia administrativa, indicando los efectos que las conductas ineficientes generan sobre los agentes públicos, la actividad administrativa y los terceros perjudicados.
\end{abstract}

Palabras clave: eficiencia administrativa; principio constitucional; interés público; control de la administración pública; responsabilidad del Estado.

\section{Daniel Wunder HACHEM* Emerson GABARDO**}

ABSTRACT: The article analyzes the principle of administrative efficiency in the Brazilian Constitution by Constitutional Amendment No. 19/1998, defending a systematic interpretation of its content in accordance with the clause of social and democratic rule of law. It presents a proposal for identification of the various consequences of the normative content of the constitutional principle of efficiency. In the end, it examines the legal consequences generated by the violation of the principle of administrative efficiency, indicating the impact that inefficient behaviors generate on public agents, on the administrative activities and people injured.

Keywords: Administrative Efficiency; Constitutional Principle; Public Interest; Control of Public Administration; State Liability.

* Doctor en derecho por la Universidad Federal de Paraná; posdoctorado en la Université Paris 1 Panthéon-Sorbonne. Profesor en la Pontifícia Universidad Católica de Paraná y la Universidad Federal de Paraná.danielhachem@gmail.com.

** Doctor en derecho por la Universidad Federal de Paraná; posdoctorado en la Fordham University School of Law, Nueva York. Profesor en la Pontificia Universidad Católica de Paraná (PUCPR) y la Universidad Federal de Paraná. e.gab@uol.com.br. 
SUMARIO: I. Introducción. II. Contexto y sentido de la positivización del principio de eficiencia en la Constitución brasileña de 1988. III. Las dimensiones del contenido jurídico complejo del principio de eficiencia administrativa para más allá del prisma estrictamente económico. IV. Consecuencias jurídicas de la actividad administrativa ineficiente. V. Conclusiones.

VI. Bibliografía.

\section{INTRODUCCIÓN}

Desde su explícita inserción entre los principios rectores de la actividad de la administración pública en el texto constitucional brasileño, tras la aprobación de la Enmienda Constitucional núm. 19/1998, el principio de eficiencia administrativa ha enfrentado fuertes desconfianzas de la doctrina. Acusado (justificadamente) de constituirse como un resultado de la ola neoliberal a mediados de los años noventa y considerado una disposición carente de contenido jurídico por advenir de una racionalidad economicista. En un escenario de avances y retrocesos, dicho principio ha conquistado cada vez más su espacio en el régimen jurídico-administrativo brasileño.

A partir del momento en que se comprende que todas las disposiciones constitucionales son normas de igual jerarquía y que se revisten de supremacía sobre el resto del ordenamiento jurídico, se llega a la indeleble conclusión de que el principio de eficiencia ostenta efectivamente una carga normativa propia, cuyo sentido debe ser atribuido desde una interpretación armónica con los postulados del Estado democrático y social de derecho y, por lo tanto, indiferente a la coyuntura política presente en el momento de su inclusión en el texto constitucional.

Partiendo de dichas premisas, este estudio tiene como objetivo delinear la configuración jurídica del principio constitucional de eficiencia administrativa, más allá de su perspectiva económica, identificando los diversos desdoblamientos extraídos de su contenido jurídico y las consecuencias de su incumplimiento por parte del Estado de cada una de las imposiciones que de él resultan. 
Esta revista forma parte del acervo de la Biblioteca Jurídica Virtual del Instituto de Investigaciones Jurídicas de la UNAM

\section{CONTEXTO Y SENTIDO DE LA POSITIVIZACIÓN DEL PRINCIPIO DE EFICIENCIA EN LA CONSTITUCIÓN BRASILEÑA DE 1988}

El principio de eficiencia en la administración pública fue expresamente consagrado en la Constitución brasileña a partir de la Enmienda Constitucional núm. 19 de 1998, que lo insertó en el caput del artículo 37 entre los principios que rigen la administración pública ya presentes en el texto constitucional desde la redacción original de la Constitución vigente, promulgada en $1988 .{ }^{1}$

La mencionada enmienda se originó en el seno de la llamada Reforma del Aparato del Estado, suscitada en los noventa, especialmente después de la edición del Plan Director de la Reforma del Estado, elaborado por el Ministerio de Administración y Reforma del Estado en $1995 .^{2}$ La idea propugnada como base de la reforma era la de reducir el aparejo del Estado con el supuesto objetivo de privilegiar la eficiencia en la gestión de la res publica y en la prestación de los servicios públicos. ${ }^{3}$

Inicialmente, según la primera propuesta de enmienda presentada en la fase de elaboración legislativa, el principio sería el de la "calidad del servicio prestado", lo que restringiría su contenido, enfocando el objeto principal del Plan Director de Reforma del Estado: el servicio público. Sin embargo, no fue la formulación final adoptada por el poder constituyente reformador, aunque sin duda en el espíritu de la reforma hayan prevalecido valores generales que tendían a la sustitución del modelo de administración burocrática por el gerencial, ${ }^{4}$ principalmente a través de la adopción

1 Constitución de la República Federativa de Brasil, 1988: “Artículo 37. La administración pública, directa, indirecta o institucional de cualquiera de los poderes de la Unión, de los estados, del Distrito Federal y de los municipios obedecerá a los principios de legalidad, impersonalidad, moralidad, y también a lo siguiente...”.

2 Brasil, Presidência da República, Câmara da Reforma do Estado, "Plano Diretor da Reforma do Aparelho do Estado". Aprovado pela Câmara da Reforma do Estado em 21.09.1995 e pelo Presidente da República. Brasília: Presidência da República, 1995, p, 17, disponible en: http://www.bresserpereira.org.br/Documents/MARE/PlanoDiretor/ planodiretor.pdf (consultada el 11 de abril de 2010).

3 Bacellar Filho, Romeu Felipe, "O regime jurídico das organizações sociais e a sua contratação pelo Poder Público mediante dispensa de licitação", en Bacellar Filho, Romeu Felipe, Reflexões sobre direito administrativo, Brasil, Fórum, 2009, p. 250.

4 La conexión entre las reglas de reforma de la Constitución y los valores constitucionales es explicada por: Albert, Richard, "The Expressive Function of Constitutional 
de un control de resultados (reduciendo la importancia de los medios y los procedimientos). ${ }^{5}$

En realidad, la previsión expresa del principio de eficiencia no ha innovado normativamente el sistema, ya que la doctrina lo reconocía implícitamente desde hace mucho ${ }^{6}$ o, por lo menos, ya se notaba su mención de modo típico en algunas de las disposiciones a lo largo del ordenamiento, con particular redacción. ${ }^{7}$ Pero no se puede negar la ampliación de su potencial de efectividad normativa o incluso la importancia simbólica de su explícita inserción en el texto constitucional. ${ }^{8}$

Si el propósito de la inserción de la eficiencia como un principio constitucional en el ordenamiento jurídico brasileño era el de conducir la organización administrativa para la dirección de un Estado subsidiario, ${ }^{9}$ de acuerdo con los ideales del neoliberalismo y con la ola de privatización que le era subyacente, esto no significa que, después del inicio de su vigencia, hayan sido éstos sus efectos jurídicos. ${ }^{10}$

Amendment Rules", Revista de Investigações Constitucionais, Brasil, vol. 2, núm. 1, 2015, pp. 7-64.

5 Con relación a la trasposición del modelo burocrático de la administración pública por el gerencial, véase: Schier Adriana da Costa, Ricardo, "Administração pública: apontamentos sobre os modelos de gestão e tendências atuais”, en Guimarães, Edgar (coord.), Cenários do direito administrativo: estudos em homenagem ao professor Romeu Felipe Bacellar Filho, Brasil, Fórum, 2004.

6 Es el caso de Hely Lopes Meirelles, que antes de la Enmienda Constitucional núm. 19/98 ya mencionaba el "deber de eficiencia" de la administración pública. Lopes Meirelles, Hely, Direito administrativo brasileiro, 16a. ed., Brasil, Malheiros, 1991, p. 86.

7 El Decreto-Ley núm. 200/67, en diversos dispositivos, ya determinaba el deber de eficiencia en la administración pública al someter la actividad del Poder Ejecutivo al control de resultado (artículos 13 y 25, V), fortalecer el sistema de mérito (artículo 25, VIII), someter a la administración indirecta a la supervisión ministerial para asegurar la eficiencia administrativa (artículo 26, III) y prever la posibilidad de despido de funcionario efectivo o estable, mediante un procedimiento administrativo, si se comprobaba la ineficiencia en el desempeño de sus atribuciones (artículo 100).

8 En cuanto al carácter simbólico de la eficiencia, utilizada como un instrumento legitimador de la actuación estatal, véase Gabardo, Emerson, Eficiência e legitimidade do Estado, Brasil, Manole, 2003.

9 Para una crítica al criterio de subsidiariedad como un determinante de los fines del Estado social, véase Gabardo, Emerson, Interesse público e subsidiariedade, Brasil, Fórum, 2009.

10 Sobre la tensión entre el derecho administrativo social y el derecho administrativo neoliberal en Brasil, véase Wunder Hachem, Daniel, "A noção constitucional de desenvolvimento para além do viés econômico: reflexos sobre algumas tendências do direito 
Afortunadamente, en los tiempos actuales, la producción de efectos jurídicos por las normas se pauta desde una hermenéutica constitucional sistemática y apoyada en los principios del ordenamiento, lo que aleja cualquier posibilidad de vinculación a la llamada mens legislatoris. Poco interés debe ser otorgado a la voluntad del legislador. La norma, después de positivizada en el sistema, pasa a ser considerada en conjunto y su contenido debe amoldarse al sentido conferido al ordenamiento jurídico a partir de su interacción con otros dispositivos normativos y axiológicos, especialmente los constitucionales. Así, se puede observar que la interpretación concedida al principio de eficiencia, después de su positivización expresa en el sistema constitucional brasileño, en nada se adecua a un modelo gerencial. Al revés: su significado es inexorablemente determinado por los paradigmas burocráticos, vigentes en la Constitución Federal de 1988, que opta por la caracterización de un Estado social y democrático de derecho cuya índole es sabidamente intervencionista. ${ }^{11}$

En este contexto, conducente a una interpretación constitucional del tema, se debe observar que a partir del momento en que la doctrina y la jurisprudencia trataron el tema empezaron a disiparse algunos mitos inherentes al principio de eficiencia. Entre las principales falacias, se destacan cuatro: 1) sería un despropósito la trasposición de un parámetro de la administración gerencial privada para la esfera pública; 2) la eficiencia no es un parámetro jurídico; 3 ) el control de la eficiencia es imposible debido a su generalidad y abstracción, y 4) hay riesgo de "derogar" otros principios en favor del principio de eficiencia. ${ }^{12}$

En primer lugar, no es procedente la afirmación de que la eficiencia es un "principio" de la administración privada, sino que en su connota-

público brasileiro", A\&C-Revista de Direito Administrativo \& Constitucional, Brasil, vol. 13, núm. 53, 2013, pp. 133-168.

11 Gabardo, Emerson, "Mecanismos de intervención del Estado en Brasil, postmodernidad y la cuestión de la subsidiariedad", Revista Eurolatinoamericana de Derecho Administrativo, Argentina, vol. 1, núm. 2, 2014, pp. 60-65. Sobre el significado de la cláusula del Estado social de derecho, véase Rodríguez-Arana Muñoz, Jaime, "La cláusula del Estado social de derecho y los derechos fundamentales sociales", Revista Eurolatinoamericana de Derecho Administrativo, Argentina, vol. 2, núm. 1, 2015, pp. 155-183; Balbín, Carlos Francisco, "Un derecho administrativo para la inclusión social", $A \& C$. Revista de Direito Administrativo \& Constitucional, Brasil, vol. 14, núm. 58, 2014, pp. 33-59.

12 Dichas afirmaciones se encuentran ampliamente debatidas en el libro Gabardo, Emerson, Princípio constitucional da eficiência administrativa, Brasil, Dialética, 2002. 
ción jurídica, es una norma. Y siendo así, la eficiencia solamente vincula a la administración pública, por lo cual ésta es quien tiene el deber de ser eficiente, ya que es la gestora de bienes que pertenecen a todos, según el principio republicano. No es posible, después de la superación del personalismo en la estructura política, admitirse la posibilidad de que la administración sea ineficiente. Dicha situación, existente, siempre configurará una patología del sistema.

En segundo lugar, es necesario que se reitere que el principio de eficiencia es una norma constitucional y, como tal, impone un deber ser, con la posibilidad de coacción o sanción (control jurisdiccional, responsabilidad funcional, responsabilidad civil, etcétera). Afirmar que la eficiencia es un principio económico o de otra ciencia (y, por lo tanto, metajurídico) es un equívoco lógico. ¿Cuál principio es ontológicamente jurídico? Quizás solamente el de legalidad. El principio democrático es esencialmente político; el de moralidad, ético; el de justicia, sociológico. El derecho se sirve de estas categorías, incluyéndolas en el sistema y atribuyéndoles juridicidad. Lo mismo ocurre con la eficiencia, y con mucha facilidad.

Como un tercer punto, cabe subrayar que diversos principios son imprecisos cuando son considerados abstractamente. Sin embargo, dicha condición no les quita la funcionalidad jurídica. ¿Hasta qué punto se puede saber, prontamente, qué es justo, moral o democrático? Aunque la comunidad jurídica reconozca la dificultad de definir dichos conceptos derivados del principio de justicia, del principio de moralidad y del principio democrático, no se les niega la condición de ser parámetros de control jurídico-normativo. Por lo tanto, la eficiencia como principio jurídico no necesita de metas predefinidas para que sea funcional y se vuelva posible su control; sino al revés, será más útil ante la ausencia de estándares (es decir, en el espacio de la discrecionalidad).

Por último, se debe considerar, como efectivamente lo está haciendo gran parte de la doctrina brasileña posterior a la reforma administrativa de los noventa, que el principio de eficiencia tiene el mismo grado de jerarquía normativa que los demás principios de la Constitución. Sin la vinculación con un caso concreto, no se puede admitir la idea de que un principio, tomado en abstracto, pueda alejar o reducir a priori el potencial 
normativo de otro principio, principalmente en el propalado seudoconflicto entre la legalidad y la eficiencia. ${ }^{13}$

El interesante desafío que se presenta después de la consagración normativa explícita del principio de eficiencia en el sistema jurídico brasileño consiste en madurar la comprensión de su real contenido jurídico como una norma constitucional, pues, aunque su inclusión expresa después de la enmienda núm. 19/1998 no haya sido una efectiva innovación (una vez que se le reconocía el carácter de norma implícita), no se puede negar que el tema se hizo público posteriormente a su incorporación textual en la Constitución, adquiriendo nuevos contornos. Cumple pues, delinear su sentido jurídico, como forma de analizar sus efectos sobre la actividad administrativa y las consecuencias de su inobservancia.

\section{LAS DIMENSIONES DEL CONTENIDO JURÍDICO COMPLEJO DEL PRINCIPIO DE EFICIENCIA ADMINISTRATIVA PARA MÁS ALLÁ DEL PRISMA ESTRICTAMENTE ECONÓMICO}

Bajo la perspectiva jurídica, el principio de eficiencia administrativa tiene una significación propia, relacionada con la observancia por parte de la administración, de determinadas formas de actuar y de las finalidades establecidas en el sistema normativo. Sin embargo, su sentido para el derecho se desarrolla en distintas dimensiones que han de ser consideradas por el intérprete.

En síntesis, y en un arriesgado intento de definición, es posible afirmar que el contenido jurídico del principio de eficiencia administrativa puede ser traducido como el deber impuesto por la Constitución a la administración pública de: 1) ejercitar la potestad administrativa que le es jurídicamente conferida con la máxima celeridad, presteza, economicidad y productividad; 2) actuar de modo a concretar fielmente la finalidad pública subyacente a las normas jurídicas a las cuales está sometida; 3) utilizar los medios más adecuados al alcance óptimo de los objetivos estatuidos por el derecho positivo (interés público); 4) conferir la máxima efectividad a los comandos que le son dirigidos por el ordenamiento jurídico, y 5) siempre

13 Véase Zanella di Pietro, Maria Sylvia, Parcerias na Administração Pública, 7a. ed., Brasil, Atlas, 2009, pp. 294 y ss. 
de acuerdo con los derechos fundamentales y con los demás principios y reglas que orientan la actividad administrativa. Es necesario analizar cada uno de estos desdoblamientos separadamente.

\section{Ejercitar la potestad administrativa que le es conferida jurídicamente} a la administración con la máxima celeridad, presteza, economicidad y productividad

Desde luego, se puede destacar como primera consecuencia del principio constitucional de eficiencia administrativa, la imposición de un deber de actuar a la administración pública. El ordenamiento jurídico — principalmente la ley en sentido estricto, pero también la Constitución- confiere a los órganos y agentes públicos determinadas potestades con un objetivo específico: el cumplimiento de un deber jurídico necesario para la satisfacción del interés público. Para ello, se atribuye una parte del poder caracterizada por un complejo de prerrogativas especiales, otorgadas al Poder Público, con el único propósito de posibilitar la consecución del bien común.

Para ejercer la función administrativa de acuerdo con el principio de eficiencia, la administración pública deberá actuar siempre que el orden jurídico le conceda un haz de atribuciones. Se prohíbe, con esto, una actuación administrativa inerte, omisa, sin compromiso con la materialización, en el mundo fáctico, de los mandamientos emanados del sistema normativo. En un Estado social y democrático de derecho como el brasileño, orientado por una Constitución dirigente, poner en marcha las imposiciones constitucionales y legales direccionadas al poder público, significa promover la satisfacción de las necesidades de la colectividad y de los intereses sociales. ${ }^{14}$

Sin embargo, el ejercicio eficiente de la función administrativa exige más que la simple acción del Estado: es necesario que la administración actúe de forma célere, ágil, económica y productiva. De nada sirve que los agentes y órganos públicos cumplan con sus funciones, si el ejercicio de dichas potestades ocurre de forma morosa, insatisfactoria, perdularia y

14 Rodríguez-Arana Muñoz, Jaime, "Dimensiones del Estado social y derechos fundamentales sociales", Revista de Investigações Constitucionais, Brasil, vol. 2, núm. 2, 2015, pp. 31-62; id., "El derecho administrativo ante la crisis (el derecho administrativo social)", Revista Eurolatinoamericana de Derecho Administrativo, Argentina, vol. 2, núm. 2, 2015, pp. 7-30. 
poco exitosa. La actividad administrativa debe cumplir con los siguientes deberes: i) celeridad: cumplimiento de las atribuciones dentro de un plazo razonable, aunque no determinado por la ley, sin dilaciones indebidas, para que no se pierda el objeto del acto o del procedimiento administrativo en cuestión, o incluso de provocar perjuicios a los destinatarios de la actividad por cuenta del retraso; ii) presteza: actuación ágil, de forma simple y objetiva, sin formalidades exacerbadas y conducentes a la paralización de la actividad administrativa, sin significar, por supuesto, la falta de respeto al trámite burocrático legalmente previsto como una garantía de la previsibilidad al ciudadano; iii) economicidad: utilización optimizada de los medios y recursos que estén a la disposición de la administración para el alcance de sus objetivos, sin desperdicios con gastos injustificados y de expresivo valor. No significa necesariamente la minimización de gastos, sino su optimización, con el objetivo de alcanzar los mayores beneficios y utilidades con el menor dispendio posible; ${ }^{15}$ iv) productividad: actuación direccionada a la producción de resultados efectivos, correspondientes con las finalidades predispuestas en la ley. Si el ordenamiento establece un deber de actuar volcado al alcance de un determinado objeto, el cumplimiento de la obligación debe producir el resultado pretendido por la norma.

De esta consecuencia se concluye que será ineficiente el comportamiento administrativo: i) omiso, por incumplir un deber de actuar establecido para la administración pública; ii) moroso, por no respetar el deber de celeridad; iii) formalista de modo exacerbado, por obstaculizar una actuación ágil y fluida, enmarcada por la simplicidad y la objetividad; iv) perdulario, por ignorar el deber de optimización de los recursos para el alcance de los mejores resultados; v) improductivo, por violar el deber de realización de los objetivos previstos por la ley para la obtención efectiva del interés público. Importa ahora analizar la segunda consecuencia jurídica antes mencionada.

15 Parejo Alfonso, Luciano, "La eficacia como principio jurídico de la actuación de la administración pública”, Documentación Administrativa, España, núms. 218 y 219, 1989 , pp. 51 y 52. 
2. Actuar de modo a concretar fielmente la finalidad pública subyacente a las normas jurídicas a las cuales la administración está sometida

La actividad administrativa, para ser eficiente, debe atender a la exacta finalidad prevista por la norma jurídica que establece al órgano o agente público, el deber de practicar determinada conducta. Los fines y medios de la actuación administrativa son aquellos fijados por el ordenamiento, pues "toda acción administrativa debe ser orientada para la concreción material y efectiva de la finalidad puesta por la ley, según los cánones del régimen jurídico-administrativo". ${ }^{16}$

El contenido jurídico del principio de finalidad no suscita gran controversia en la doctrina. En una amplia acepción, la finalidad se refiere a la exigencia de un resultado según el interés público genéricamente considerado o, en una connotación restricta, se reporta al resultado exigido explícita o implícitamente por ley específica que rige el caso concreto. De cualquier manera, es cierto que la actuación del administrador, en todos los actos de gestión - sean ellos de carácter político o propiamente administrativo - debe respaldarse por una finalidad pública condicionada también por ley.

Sin embargo, se podría alegar que algún debate se ubica sobre el sentido que es asignado al principio de legalidad como un elemento orientador de la finalidad. Diversos autores entienden que la legalidad debe ser interpretada en sentido amplio, significando el deber de respetar el derecho como un todo (y no sólo la ley formal). ${ }^{17}$ En este sentido, la legalidad tendría el mismo significado del "principio de juridicidad". ${ }^{18}$ Adoptando posición contraria, explica Romeu Felipe Bacellar Filho que es más adecuado afirmar la sumisión de la administración al principio de legalidad en sentido estricto y, separadamente, a los demás principios y reglas extraídas del sistema constitucional. ${ }^{19}$ Es decir: el deber de respeto al principio de le-

${ }^{16}$ França, Vladimir da Rocha, "Eficiência administrativa na Constituição Federal", Revista de Direito Administrativo, Brasil, núm. 220, 2000, p. 168.

17 Zanella di Pietro, Maria Sylvia, Discricionariedade administrativa na Constituição de 1988, Brasil, Atlas, 1991, p. 97.

18 Soto Kloss, Eduardo, "Derecho administrativo. Bases fundamentales”, El principio de juridicidad, Chile, Jurídica de Chile, 1996, t. II; Antunes Rocha, Cármen Lúcia, Princípios constitucionais da administração pública, Brasil, Del Rey, 1994, pp. 83 y ss.

19 En las palabras del autor: "La adopción del sentido restricto del principio de legalidad es una exigencia de la Constitución de 1988 misma. El primer argumento es de orden 
galidad significaría respeto por la administración a la ley formal, mientras que el principio de juridicidad comprendería el deber de respeto no sólo a la legalidad estricta (ley formal), sino también a todos los demás elementos del derecho.

Considerando dicha dicotomía hermenéutica, es posible unir las nociones (que en su contenido no discrepan) a partir del posicionamiento de Diogo de Figueiredo Moreira Neto, para quien la actuación administrativa, principalmente la discrecional, debe ser controlada por la legalidad y por la legitimidad (cuya yuxtaposición resulta de la necesaria satisfacción del interés público). ${ }^{20} \mathrm{El}$ control de legalidad demandaría el análisis del cumplimiento o no de la ley formal (principio de legalidad), mientras que el control de legitimidad, más amplio, implicaría el examen del cumplimiento o no de todos los elementos que integran el derecho (principio de juridicidad).

En esta línea de raciocinio, sería posible aún pensar si el principio de eficiencia no coincide con el principio de finalidad, pues ambos objetivan el cumplimiento óptimo del interés púbico, más allá de la legalidad estricta. Sin duda la aproximación es grande, pero no hay coincidencia. Como aclara Vladimir da Rocha França,

mientras que en el principio de eficiencia administrativa se determina que la acción material de la administración pública deba alcanzar efectivamente, y de modo lícito, la finalidad legal, el principio de finalidad aclara que el acto administrativo solamente puede tener una finalidad pública, establecida en la ley. ${ }^{21}$

La relación es de un condicionamiento recíproco entre principios distintos que deben - cada uno- someterse al control jurisdiccional.

La correspondencia de la actividad administrativa con la finalidad que le es prevista por ley, constituye un importantísimo elemento de evalua-

lógico. Si el principio de legalidad pretendiera abarcar la propia vinculación constitucional de la actividad administrativa sería inútil y totalmente carente de sentido la afirmación de otros principios constitucionales de la administración pública. Al final, ¿qué contenido jurídico sobraría para los demás?", Bacellar Filho, Romeu Felipe, Processo administrativo disciplinar, 3a. ed., Brasil, Saraiva, 2011, p. 166.

${ }^{20}$ Moreira Neto, Diogo de Figueiredo, Legitimidade e discricionariedade: novas reflexões sobre os limites e controle da discricionariedade, 2a. ed., Brasil, Forense, 1991, p. 15.

21 França, Vladimir da Rocha, "Eficiência administrativa na...”, cit., p. 171. 
ción de su eficiencia en cualquier área de actuación de la administración pública. Por ejemplo, en el caso de la actividad de la policía administrativa, el administrador, al ejercitar el poder de policía, solamente será eficiente si el acto o procedimiento fuera realizado con la intención de limitar las libertades individuales, objetivando asegurar el orden público — finalidad subyacente a las actividades de policía administrativa. ${ }^{22} \mathrm{Si}$ la restricción de los derechos de un determinado individuo no tiene como justificación la garantía del normal ejercicio de los derechos y libertades de los demás ciudadanos, objetivando algo distinto, ${ }^{23} \mathrm{el}$ acto o procedimiento violará el principio de eficiencia.

Lo mismo ocurre con el servicio público. Como a esta actividad corresponde la finalidad de "satisfacer una necesidad pública", ${ }^{24}$ se le impone a la administración la obligación de mantener un servicio público adecuado, según se extrae del artículo 175, párrafo único, IV de la Constitución brasileña. En contrapartida, recae sobre el ciudadano la titularidad de un derecho al servicio público adecuado, cuyo contenido puede extraerse de los principios que componen el régimen jurídico de los servicios públicos, ${ }^{25}$ estatuidos en el artículo 6o., §10. de la Ley 8.987/95. ${ }^{26}$ En el caso de que la prestación de los servicios públicos sea marcada por la no observancia

22 Laubadère, André de, Traité élémentaire de droit administratif, 3a. ed., Francia, LGDJ, 1963, t. I, p. 505.

${ }^{23}$ Garrido Falla, Fernando, Tratado de derecho administrativo, 12a. ed., España, Tecnos, 2006, vol. II, p. 165.

24 Gordillo, Agustín, Tratado de derecho administrativo. La defensa del usuario y del administrado, 5a. ed., Argentina, Del Rey-Fundación de Derecho Administrativo, 2003, t. II, pp. 6-34.

25 Sobre la gestión eficiente de los servicios públicos, véase Sacristán, Estela, "Gestión eficiente y ética en la efectivización de los servicios públicos relativos a derechos sociales", Revista de Investigações Constitucionais, Brasil, vol. 3, núm. 1, 2016, pp. 125 143.

26 Wunder Hachem, Daniel, "Direito fundamental ao serviço público adequado e capacidade econômica do cidadão: repensando a universalidade do acesso à luz da igualdade material", A\&C-Revista de Direito Administrativo \& Constitucional, Brasil, vol. 14, núm. 55, 2014, pp. 123-158; Schier, Adriana da Costa Ricardo, Regime jurídico do serviço público: garantia fundamental do cidadão e proibição de retrocesso social, Tesis de Doctorado en Derecho del Estado, Brasil, Sector de Ciencias Jurídicas, Universidade Federal do Paraná, 2009, p. 129; Finger, Ana Cláudia, "Serviço público: um instrumento de concretização de direitos fundamentais", A\&C-Revista de Direito Administrativo \& Constitucional, Brasil, vol. 3, núm. 12, 2003, pp. 142-165. 
de alguno de aquellos principios — $-v$. g. la continuidad — la actividad resultará ineficiente por incumplir la finalidad que le fue impuesta por ley.

\section{Utilizar los medios más adecuados para el alcance óptimo de los objetivos estatuidos por el derecho positivo (interés público)}

Es posible afirmar que el efecto más importante proporcionado por la positivización del principio de eficiencia es su reconocimiento como un mecanismo de control del punto óptimo en la actuación administrativa. Celso Antônio Bandeira de Mello, aunque se reconozca el valor a dicho principio, fue quien desarrolló de forma más detallada en Brasil la idea de control del punto óptimo, es decir, del deber que recae sobre el poder público de producir, en sus acciones, el efecto útil y adecuado de la mejor manera posible. ${ }^{27}$

La eficiencia del Estado supone la plena realización del interés público, cuyo contenido jurídico debe ser encontrado en el propio derecho positivo. ${ }^{28}$ Para alcanzar los fines determinados por el ordenamiento jurídico, se dota al administrador con diversos medios, mecanismos y procedimientos posibles, dentro del espectro de la legalidad. Sin embargo, no basta actuar regularmente sobre los caminos de la ley y en la dirección de la finalidad subyacente a la norma: es necesario optar por los instrumentos más adecuados para alcanzar el punto óptimo en la actuación administrativa. Si entre dos o más posibilidades legalmente admisibles, existe una que proporciona un resultado más productivo, se reduce el ámbito de discrecionalidad administrativa y la elección del medio óptimo se impone como un deber al administrador.

27 La tesis es desarrollada en su libro sobre discrecionalidad administrativa. Cfr. Bandeira de Mello, Celso Antônio, Discricionariedade e controle jurisdiccional, 2a. ed., Brasil, Malheiros, 2003.

28 Bandeira de Mello, Celso Antônio, Grandes temas de direito administrativo, Brasil, Malheiros, 2009, p. 189; Wunder Hachem, Daniel, "A dupla noção jurídica de interesse público em direito administrativo", A\&C-Revista de Direito Administrativo \& Constitucional, Brasil, vol. 11, núm. 44, 2011, pp. 59-110. Sobre la relación entre el contenido del interés público y los derechos fundamentales. Meilán Gil, José Luis, "Intereses generales e interés público desde la perspectiva del derecho público español”, A\&C-Revista de Direito Administrativo \& Constitucional, Brasil, vol. 10, núm. 40, 2010, pp. 171-198. 
Algunos autores suelen observar en esta dimensión del principio de eficiencia una estrecha aproximación con la idea de "buena administración", ${ }^{29}$ principalmente después de la positivización del derecho fundamental a una buena administración en el artículo 41 de la Carta de Derechos Fundamentales de la Unión Europea ${ }^{30}$ El asunto merecería un análisis más detenido, ante la gran cantidad de bibliografía acerca del tema. ${ }^{31}$ Empero, cabe destacar que la idea de eficiencia parece superar tanto el sentido simbólico como el punto de vista estrictamente lógico del deber de "buena administración”. Además, constituye un norte más adecuado para la satisfacción eficaz del interés público. ¿Por qué cabría al poder público un deber de "buena" y no de óptima administración? Ante diversas opciones razonables, insertadas en el margen conferido al administrador por la ley, ¿no estaría cumplido el deber de "buena administración”, aunque el agente eligiera un medio idóneo, pero menos eficiente? ¿No se estaría con esto admitiendo la posibilidad de elección de un buen mecanismo en perjuicio

${ }^{29}$ Véase Meilán Gil, José Luis, "Una construcción jurídica de la buena administración”, A\&C-Revista de Direito Administrativo \& Constitucional; Rodríguez-Arana Muñoz, Jaime, "Sobre el derecho fundamental a la buena administración y la posición jurídica del ciudadano", A\&C-Revista de Direito Administrativo \& Constitucional, Brasil, vol. 12, núm. 47, 2012, pp. 13-50; Falzone, Guido, Il dovere di buona amministrazione, Italia, Giuffrè, 1953; Andreani, Antonio, Il principio costituzionale di buon andamento della publica amministrazione, Italia, CEDAM, 1979.

${ }^{30}$ Ponce Solé, Juli, Deber de buena administración y derecho al procedimiento administrativo debido: las bases constitucionales del procedimiento administrativo y del ejercicio de la discrecionalidad, España, Lex Nova, 2001; Tomás Mallén, Beatriz, El derecho fundamental a una buena administración, España, INAP, 2004; Rodríguez-Arana Muñoz, Jaime, Direito fundamental à boa administração pública, trad. de Daniel Wunder Hachem, Brasil, Fórum, 2012; id., "El derecho fundamental a la buena administración en la Constitución española y en la Unión Europea", $A \& C$-Revista de Direito Administrativo \& Constitucional, Brasil, vol. 10, núm. 40, 2010, pp. 117-149.

31 Para un análisis más profundizado, véase Galera Rodrigo, Susana, "El derecho a una buena administración”, en Álvarez Conde, Enrique y Garrido Mayol, Vicente (dirs.), Comentarios a la Constitución Europea, España, libro II: Los derechos y libertades, 2004, pp. 1441-1465; Söderman, Jacob, "El derecho fundamental a la buena administración", Gaceta Jurídica de la Unión Europea y de la Competencia, España, núm. 214, 2001, pp. 8-14; González Alonso, Luis N., "Artículo 41: Derecho a una buena administración”, en Mangas Martín, Araceli (dir.), González Alonso, Luis N. (coord.), Carta de los Derechos Fundamentales de la Unión Europea: comentario artículo por artículo, España, Fundación BBVA, 2008, pp. 665-677; Ruocco, Graciela, “La «buena administración» y el «interés general»”, A\&C-Revista de Direito Administrativo \& Constitucional, Brasil, vol. 12, núm. 49, 2012, pp. 27-45. 
de uno óptimo para la consecución de la finalidad del acto? La imposición de un deber de eficiencia a la administración pública parece ser más apropiada en el sentido de conducir la actividad administrativa al alcance efectivo de la finalidad pública, disminuyendo sustancialmente el margen de discrecionalidad del administrador, a menos que el "bueno" sea entendido como un "óptimo" (como efectivamente entiende parte de la doctrina). Sin embargo, dicha opción científica no deja de ser mínimamente rara, para no decir totalmente paradójica. Al final, el bueno es sólo razonable, es decir, el mínimo satisfactorio ante un objetivo determinado.

La tradicional teoría de los actos administrativos divide la actividad administrativa en reglada (que no deja ningún margen de apreciación subjetiva por el agente, obligándolo a actuar de una manera u otra en función de la realización, en el mundo fáctico, de determinados requisitos legales) y discrecional (cuya actuación del agente no estaría completamente descripta en la ley, restando, por ende, un margen de intelección subjetiva). Dicha división, de extremada complejidad, viene prestándose como un fundamento para la no apreciación judicial de un inmenso conjunto de actos administrativos. ${ }^{32}$

En el espacio de la actuación reglada, la importancia del principio de eficiencia es, en cierta manera, reducida por la preponderancia de los principios de legalidad y finalidad, lo que no lleva a su inaplicabilidad en dichas situaciones. Es cierto que el cumplimiento de la ley y el alcance de su finalidad desde luego aproximan el acto de la realización del principio de eficiencia. Sin embargo, no basta actuar según la ley: es necesario que la acción observe los deberes de celeridad, presteza, economicidad y productividad. Por ejemplo, se puede mencionar la situación de un acto de concesión de jubilación, en la que un servidor público ha cumplido con todos los requisitos previstos en ley para jubilarse, vinculando la administración a la práctica del acto concesivo. Empero, en dicha situación hipotética la apreciación del pedido llevó meses para concluirse, resultando en una actividad que atendió a los principios de legalidad y de finalidad, pero que violó el principio de eficiencia.

Aunque se pueda considerar la incidencia del principio de eficiencia administrativa en las actividades regladas, es principalmente en el campo de la discrecionalidad donde la inclusión expresa del principio de efi-

32 Oliveira Moraes, Germana de, Controle jurisdicional da administração pública, Brasil, Dialética, 1999, p. 28. 
ciencia sobrepasa las tradicionales barreras de la imposibilidad del control total de los actos administrativos. Particularmente en lo que se refiere al importante tema de su control jurisdiccional, tan debatido en el derecho brasileño, se vuelve urgente la conexión de cuestiones de gestión, eficiencia, discreción y control. Afirmar la posibilidad de control jurisdiccional de la actuación discrecional del agente público por medio de la evaluación del cumplimiento del principio de eficiencia puede ser considerado como algo imposible — una verdadera utopía - . Debido a raíces históricas del control jurisdiccional en el Estado moderno, que remonta a la desconfianza de los revolucionarios franceses en relación con el Poder Judicial, cabe destacar que incluso el sistema de jurisdicción única terminó por restringir la posibilidad de control del acto administrativo discrecional. ${ }^{33}$ Empero, dicha realidad viene alterándose paulatinamente. ${ }^{34}$

Con la incorporación de principios como eficiencia, moralidad y razonabilidad al sistema jurídico, surgen nuevos criterios para la evaluación de la conformidad de los actos administrativos con el derecho. Así, como no siempre es posible afirmar que un acto es "objetivamente reputado como incorrecto", muchas veces no existirán condiciones objetivas de evaluación de la eficiencia de la actuación. En la práctica administrativa pueden surgir tanto situaciones en las que hay seguridad absoluta, como otras en las que hay dudas (en este último caso, se admite más que una hipótesis como razonable). De esta manera, en una situación real, si el administrador actúa de una forma razonable (aunque existiendo otra también razonable, pero divergente), no es posible reputar como ilegítimo el acto. ${ }^{35}$ Cabe observar aquí que no se está tratando del principio de razonabilidad.

De otra parte, en la secuencia de este raciocinio, podría emerger la siguiente cuestión: ¿cuál es entonces, la relación entre eficiencia y razonabi-

${ }^{33}$ El desarrollo del modelo francés de jurisdicción es explicado por Jordão, Eduardo, "La dynamique de la déférence: création et évolution des modèles auto-restrictives de contrôle juridictionnel dans le droit comparé", Revista de Investigações Constitucionais, Brasil, vol. 2, núm. 3, 2015, pp. 111-135.

34 Véase Pondé Fonseca, Juliana, "The Vanishing Boundaries between Technical and Political: Normativism and Pragmatism in the Brazilian Courts' Adjustment of Public Policies", Revista de Investigações Constitucionais, Brasil, vol. 2, núm. 3, 2015, pp. 6181; Muller Bitencourt, Caroline, "Sobre o possível controle judicial de políticas públicas: um olhar a partir do campo de conformação do legislador e do administrador", Revista Eurolatinoamericana de Derecho Administrativo, Argentina, vol. 2, núm. 2, 2015, pp. 143-166.

35 Bandeira de Mello, Celso Antônio, Discricionariedade e controle..., cit., p. 23. 
lidad? Moreira Neto entiende que el acto ineficiente viola el principio de razonabilidad, una vez que dicha actuación igualaría la "buena administración" a la "mala administración". Merece registro el ablandamiento que el autor hace de su propuesta, cuando afirma que solamente la "violación grosera" de la eficiencia caracterizaría la no razonabilidad. ${ }^{36}$ Sin embargo, aunque en la práctica quizás las consecuencias fueran las mismas, mejor es el raciocinio que puede ser extraído de la doctrina de Bandeira de Mello, para quien la necesaria actuación óptima resulta en más que una actuación razonable o proporcional. Así, es posible comprender que un acto puede que sea razonable, pero ineficiente, aunque siempre que sea eficiente será también razonable.

Cuando se tiene dos o más posibilidades razonables, no se está haciendo referencia al "principio de razonabilidad", sino que se está averiguando, lógicamente, la posibilidad de dos respuestas igualmente admisibles en lo que respecta a la eficiencia (o cualquier otro requisito de validez a ser considerado). Si se considera que no existen actos exclusivamente políticos, "de suerte que el administrador tiene el compromiso con lo óptimo o, al menos, con la optimización", ${ }^{37}$ se vuelve más fácil la comprensión del raciocinio.

El principio de eficiencia sobrepasa los límites del principio de razonabilidad en la medida que resulta en una mayor exigencia, derivada del cumplimiento del principio de finalidad, que impone no solamente una actuación buena o suficiente (razonable/racional), sino óptima (la mejor posible). Es decir: entre dos opciones que observan el principio de razonabilidad, debe el administrador optar por la más eficiente. Con la constitucionalización del principio de eficiencia, ésta se vuelve un criterio jurídico para la evaluación de la conformidad del acto con el derecho. En este sentido, el Poder Judicial sobrepasa la mera averiguación de la existencia de "desvío de poder" para investigar la existencia de una actuación inconveniente o inoportuna, bajo la perspectiva de la eficiencia.

Esto no resulta en una interferencia en la actividad administrativa por medio de elecciones a ser tomadas por el Poder Judicial, pues cuando se presente una decisión política, jurídicamente perfecta (a partir del juicio de razonabilidad), no hay posibilidad de que el acto tenga algún vicio en

${ }^{36}$ Moreira Neto, Diogo de Figueiredo, Legitimidade e discricionariedade..., cit., p. 57.

37 Freitas, Juarez, $O$ controle dos atos administrativos e os principios fundamentais, 2a. ed., Brasil, Malheiros, 1999, p. 83. 
lo que se refiere a su gestión. Los atributos de conveniencia y oportunidad no se pueden escapar más del control jurisdiccional, que debe realizar un juicio de compatibilidad entre el mérito del acto y el sistema constitucional como un todo (principio de juridicidad o de legalidad en sentido amplio).

El potencial jurídico del principio de eficiencia, principalmente después de su constitucionalización, es capaz de revertir el consolidado entendimiento de los tribunales superiores brasileños en el sentido de que no es posible al Poder Judicial controlar la eficiencia del acto administrativo. Cada vez más, a partir de la positivización expresa del principio en la Constitución, habrá la posibilidad de análisis por el Poder Judicial de cuestiones antes alejadas de su alcance por la jurisprudencia. ${ }^{38}$

\section{Conferir la máxima efectividad a los comandos que son dirigidos a la administración por el ordenamiento jurídico}

Otra dimensión del principio de eficiencia está en el efecto maximizador por él proporcionado a los demás principios y reglas que rigen la administración pública. El actuar administrativo sólo es eficiente cuando concreta el conjunto normativo que le es aplicable de manera óptima. Así, la eficiencia en el cumplimiento de los mandamientos constitucionales y legales, representa también la necesidad de extraer el contenido más amplio que se pueda retirar de dichas disposiciones. Se trata de una función servicial del principio en cuestión, destinada a la realización efectiva del orden constitucional. En este sentido dispone la Sentencia núm. 178/1989 del Tribunal Constitucional Español. ${ }^{39}$

Se puede tener como ejemplo el principio de publicidad: si compete al administrador el deber de divulgación y transparencia, sus actos debe-

38 Corvalán, Juan G., "Los ejes centrales de la división de poderes en el Estado constitucional de derecho", Revista de Investigações Constitucionais, Brasil, vol. 2, núm. 1, 2015, pp. 236-237.

39 STC núm. 178/1989: "Si la Constitución proclama expresamente en su artículo 1.1, que España se constituye en un Estado social y democrático de derecho, una de sus consecuencias es, sin duda, la plasmación real de sus valores en una organización que, legitimada democráticamente, asegure la eficacia en la resolución de los conflictos sociales y la satisfacción de las necesidades de la colectividad, para lo que debe garantizarse la existencia de unas administraciones públicas capaces de cumplir los valores y los principios consagrados constitucionalmente". Cfr. Parejo Alfonso, Luciano, "La eficacia como principio...", cit. 
rán ser divulgados de la mejor forma en todos los medios disponibles, de la manera más transparente posible. Para el eficiente cumplimiento del principio de publicidad, no basta que el acto no sea sigiloso, es menester que él sea divulgado internamente y, cuando el ordenamiento así lo exija, también externamente.

Lo mismo ocurre con los demás principios constitucionales de la administración pública. La moralidad administrativa no puede ser entendida restrictivamente, solamente como un deber ético de probidad y honestidad. El cumplimiento eficiente del imperativo constitucional de la moralidad supone su comprensión global, que abarca también el perfil de previsibilidad y lealtad en el actuar administrativo, "no habiendo sitios para trampas, sorpresas o imprevistos que caractericen una «administración de sorpresas $» " .^{40}$ La observancia eficiente del principio de moralidad requiere una actuación pautada no sólo en la ética, sino también en la seguridad de las relaciones jurídicas ${ }^{41}$ y en la protección de la confianza legítima del ciudadano. ${ }^{42}$

Dicha consecuencia del principio de eficiencia, de potencializar el contenido normativo y axiológico de los demás comandos del ordenamiento jurídico, coincide con el llamado principio de máxima efectividad, aplicable a la hermenéutica constitucional, según el cual, deberá ser atribuido al texto normativo en el acto de construcción interpretativa de la norma, el significado que mayor efectividad le dé, optimizando y maximizando su contenido, de modo a conferirle una mayor potencialidad. ${ }^{43}$ Así, todos los principios y reglas dirigidos a la administración pública, especialmente los que configuran derechos fundamentales, deben ser interpretados de manera maximizada.

Es el caso del derecho fundamental a una amplia defensa en el procedimiento administrativo disciplinario. Su interpretación debe llevar en

${ }^{40}$ Bacellar Filho, Romeu Felipe, "A estabilidade do ato administrativo criador de direitos à luz dos princípios da moralidade, da segurança jurídica e da boa-fé", $A \& C$-Revista de Direito Administrativo \& Constitucional, Brasil, vol. 10, núm. 40, 2010, p. 300.

41 Alianak, Raquel Cynthia, "Seguridad jurídica, buena fe y confianza legítima frente a actos estatales", Revista Eurolatinoamericana de Derecho Administrativo, Argentina, vol. 2, núm. 2, 2015, pp. 85-97.

42 Cassagne, Juan Carlos, "El nuevo constitucionalismo y las bases del orden jurídico", Revista de Investigações Constitucionais, Brasil, vol. 2, núm. 1, 2015, pp. 213 y 214.

43 Gomes Canotilho, J. J., Direito constitucional e teoria da Constituição, 7a. ed., Portugal, 2003, p. 1224. 
consideración los diversos desdoblamientos de este principio. De esta forma, un funcionario público acusado de practicar una falta funcional puede ejercer la autodefensa, pues ésta representa uno de los elementos que componen el derecho de defensa. Sin embargo, la autodefensa por sí sola no es suficiente para que la defensa sea realmente amplia. A su lado, debe ser garantizada la defensa técnica, una vez que será solamente a través de ella que se podrá evaluar la argumentación defensiva y extraer los fundamentos jurídicos aptos para fortalecer la contestación del acusado. Es de aquí que el principio de eficiencia, en vez de justificar una supuesta innecesaridad en la defensa técnica de abogado en el procedimiento administrativo disciplinario, impone su observancia, lo que resulta en la inconstitucionalidad de la "Súmula Vinculante núm. 5" del Supremo Tribunal Federal brasileño, según la cual "La falta de defensa técnica por abogado en el procedimiento administrativo disciplinario no ofende la Constitución". ${ }^{44}$

\section{Actuar siempre de acuerdo con los derechos fundamentales y con los demás principios y reglas que orientan a la actividad administrativa}

El quinto elemento que compone el concepto de eficiencia administrativa propuesto en este estudio resalta la obviedad de que dicho principio constitucional, como todos los demás, no goza de superioridad jerárquica en relación con cualquier norma de la Constitución. Su comprensión debe darse de forma conjunta con los demás principios y reglas dirigidos a la actividad administrativa, jamás pudiéndose, en nombre de la eficiencia, sacrificar el contenido esencial de cualquier otro principio del régimen jurídico administrativo, especialmente los que definen derechos fundamentales.

La eficiencia no exige la renuncia a cualquier conquista del Estado de derecho, de modo que la contraposición a priori entre "actuación confor-

44 Véase Bacellar Filho, Romeu Felipe y Wunder Hachem, Daniel, “A necessidade de defesa técnica no processo administrativo disciplinar e a inconstitucionalidade da Súmula Vinculante núm. 5 do STF", A\&C-Revista de Direito Administrativo \& Constitucional, Brasil, vol. 10, núm. 39, 2010, pp. 27-64. Sobre la no obligatoriedad de abogado en el procedimiento administrativo en Perú, véase Huapaya Tapia, Ramón A., "El derecho constitucional al debido procedimiento administrativo en la ley del procedimiento administrativo general de la República del Perú", Revista de Investigações Constitucionais, Brasil, vol. 2, núm. 1, 2015, p. 152. 
me la legalidad" versus "actuación eficiente" representa una falsa paradoja. En la hipótesis de existir un eventual conflicto, en el caso concreto, entre el principio de legalidad y el de eficiencia — colisión que, obvio está, puede ocurrir entre otros principios - bastará "determinar las condiciones en que la actuación de la administración, siendo conforme al derecho, sea también efectiva, idónea para la satisfacción real de los intereses generales". ${ }^{45}$ Por lo tanto, no hay razón para negar el carácter jurídico al principio de eficiencia, dada su plena compatibilidad con el Estado de derecho y con el principio de legalidad, desde que se comprenda su sentido y su naturaleza jurídica de principio.

Conforme los desdoblamientos anteriores, el incumplimiento de la legalidad $-\mathrm{y}$, por consiguiente, de la finalidad prevista por el ordenamiento jurídico- resultará en violación al propio principio de eficiencia, que tiene como una de sus dimensiones, la imposición a la administración del deber de alcanzar la finalidad pública subyacente a cada norma del sistema jurídico.

\section{CONSECUENCIAS JURÍdICAS DE LA ACTIVIDAD}

ADMINISTRATIVA INEFICIENTE

A partir de la comprensión del contenido jurídico del principio constitucional de eficiencia administrativa y sus diversos desdoblamientos ya expuestos, resulta fácil trazar los diferentes deberes a los que la administración pública se somete por cuenta de la positivización de dicho principio, en rango constitucional. La inobservancia de las obligaciones emanadas de la norma en cuestión, suscita, como no podría ser diferente, variados efectos en el mundo jurídico.

El incumplimiento de dichas imposiciones, extraídas del principio de eficiencia, resultará en por lo menos tres consecuencias jurídicas objetivas y bien definidas: 1) en lo que se refiere a los agentes públicos, la inobservancia de los mandamientos originados del deber de eficiencia podrá resultar en su responsabilidad personal, en las esferas administrativa, civil y penal; 2) en cuanto a la actividad practicada, su no conformidad con los comandos emanados del principio en referencia, resulta en la sujeción del acto (o procedimiento) al control interno o externo, que debe ser puesto en

45 Parejo Alfonso, Luciano, “La eficacia como principio...”, cit., pp. 32 y 33. 
marcha para corregir la actuación administrativa ineficiente, y 3) con respecto a los terceros alcanzados por los efectos de la actividad, los perjuicios experimentados en consecuencia de la actuación violadora del principio de eficiencia generará la responsabilidad civil del Estado, desde que estén presentes los elementos configuradores del deber de reparar el daño. Cabe examinar, aunque sea resumidamente, cada una de ellas.

\section{Con relación a los agentes públicos: responsabilidad personal del agente ineficiente}

Los agentes públicos que no respetan los deberes resultantes del principio de eficiencia, se sujetarán al régimen de responsabilidad personal. Las sanciones podrán tener una naturaleza administrativa, toda vez que la actuación ineficiente derive de la afronta a los deberes funcionales instituidos por los estatutos de los funcionarios públicos — como la Ley núm. 8.112/90, dirigida a los servidores públicos federales - y por las leyes que componen el régimen jurídico de las demás especies de agentes públicos —como el Decreto-Ley núm. 201/67, sobre las responsabilidades de alcaldes y concejales-.

Se puede citar como ejemplo la situación del funcionario público que falta frecuentemente y que no es puntual en el horario, que incumple el deber de asiduidad y de puntualidad en el servicio (artículo 116, X de la Ley núm. 8.112/90), o del alcalde que retrasa la publicación o que deja de publicar las leyes y actos sujetos a dicha formalidad (artículo 4o., IV del Decreto-Ley núm. 201/67). El agente será personalmente sancionado en razón de su ineficiencia, sujetándose a las sanciones legales.

Otro ejemplo simbólico de una sanción administrativa aplicable al funcionario debido a la ineficiencia del ejercicio de sus funciones, que fue introducida por la misma enmienda constitucional que positivizó el principio de eficiencia (núm. 19 de 1998), es la "nueva" posibilidad de la pérdida del cargo por funcionarios estables: la insuficiencia de desempeño, prevista en el artículo 41, §10., III de la Constitución. ${ }^{46}$ Obviamente, conforme atestan diversos autores, "dicho tema indudablemente depende de reglamentación infraconstitucional", en la medida que se vuelve necesario

46 Constitución de la República Federativa de Brasil de 1988: “Artículo 41...§ 1o. El servidor público estable perderá el cargo... III. Mediante procedimiento de evaluación periódica de desempeño, en la forma de ley complementaria, asegurada amplia defensa". 
"que esta legislación observe las garantías del contradictorio y de la amplia defensa, como también que asegure al funcionario público unos criterios objetivos y claros para contrastar la eficiencia de su conducta funcional" ${ }^{47}$ No es exageración que se recuerde que la aplicación de cualquier tipo de sanción a los agentes públicos deberá ser precedida de un procedimiento administrativo, con una rigurosa observancia de todos los derechos fundamentales que componen el núcleo común de los procedimientos incorpora en el tejido constitucional, como el del juez natural (artículo 5o., LIII), del debido proceso legal (artículo 5o., LIV), ${ }^{48}$ el contradictorio y la amplia defensa (artículo 5o., LV), la presunción de inocencia (artículo 5o., LVII) ${ }^{49}$ y la duración razonable del proceso (artículo 5o., LXXVIII). ${ }^{50}$

La responsabilidad del agente podrá ser, por otro lado, de naturaleza civil en las hipótesis que su ineficiencia resulte en lesión a la hacienda pública. Es menester en estos casos que el daño haya sido experimentado por la propia persona jurídica a la que el agente esté vinculado. De lo contrario - por ejemplo, en el caso de funcionario público municipal que, debido a un convenio celebrado por el municipio, genera perjuicios a la Unión Federal, por ineficiencia - será necesaria la previa condenación de la entidad a la que pertenece el funcionario, y sólo posteriormente, por la vía regresiva, mediante la comprobación de dolo o culpa, el agente podrá ser personalmente condenado a reparar los daños causados a la persona jurídica de la cual él hace parte. Dicho entendimiento encuentra un fuerte apoyo en la doctrina ${ }^{51}$ y en la jurisprudencia del Supremo Tribunal Federal.

47 França, Vladimir da Rocha, "Eficiência administrativa na...", cit., p. 173.

48 Galera Rodrigo, Susana, "The Right to a Fair Trial in the EU: Lights and Shadows", Revista de Investigações Constitucionais, Brasil, vol. 2, núm. 2, 2015, pp. 7-29.

49 Bacellar Filho, Romeu Felipe, "O direito fundamental à presunção de inocência no processo administrativo disciplinar", A\&C-Revista de Direito Administrativo \& Constitucional, Brasil, vol. 9, núm. 37, 2009, pp. 11-55.

50 Wunder Hachem, Daniel, "Processos administrativos reivindicatórios de direitos sociais: dever de decidir em prazo razoável vs. silêncio administrativo", A\&C-Revista de Direito Administrativo \& Constitucional, Brasil, vol. 14, núm. 56, 2014, pp. 147-175, Bacellar Filho, Romeu Felipe, Processo administrativo..., cit.

51 Lopes Meirelles, Hely, Direito administrativo..., cit., p. 555; Nogueira, Paulo Lúcio, Administração e responsabilidade dos prefeitos e vereadores, Brasil, Sugestões Literárias, 1974, p. 64; Bernardi, Ovídio, "Responsabilidade dos prefeitos municipais: políticas, político-administrativas, civis e criminais", Revista dos Tribunais, Brasil, 1962, pp. 76 y 77. 
Finalmente, la responsabilidad podrá ser de orden criminal, en las situaciones en que la conducta ineficiente coincida con la descripción normativa prevista en un tipo penal. Se puede mencionar la hipótesis del delito de malversación culposa, definido en el artículo 312, §2o. del Código Penal como una situación en la que el agente actúa culposamente - es decir, en razón de su negligencia, imprudencia o impericia (o, en otras palabras, ineficiencia) - para la apropiación de dinero, valor u otro bien mueble por parte de otro.

\section{Con relación a las actividades administrativas: control interno y externo de las conductas ineficientes}

Las actividades administrativas que no estén en armonía con las imposiciones constitucionales del principio de eficiencia deberán ser corregidas inmediatamente mediante el control interno, ejercido primordialmente mediante el ejercicio de la potestad de autotutela de la administración pública. Los actos con vicio de ilegalidad representarán, evidentemente, actos ineficientes, ya que no se prestan para el alcance de la finalidad que les fue impuesta por el sistema normativo. La corrección deberá ser proporcionada por medio del instituto de la anulación (por motivos de ilegalidad), como determinan los artículos 53 de la Ley núm. 9.784/99 y de la "Súmula núm. 473" del Supremo Tribunal Federal brasileño. Si el vicio puede ser subsanado, por consecuencia de la propia noción de eficiencia, el administrador estará sujeto al deber de convalidación, dada la onerosidad y la innecesaridad de repetición de todo el procedimiento exigible para la práctica de un nuevo acto, desde que tal corrección no ocasione lesión al interés público o perjuicios a terceros, según establece el artículo 55 de la Ley de Procedimiento Administrativo en el ámbito federal..$^{52}$

A su vez, los actos practicados en conformidad con la ley, pero en disonancia con la conveniencia y la oportunidad, se transformarán en actos contrarios al derecho, por atentatorios al principio de eficiencia. La revocación del acto ineficiente por motivos de interés público se vuelve, asimismo, un deber del administrador (artículo 53, Ley núm. 9.784/99). La evaluación de la eficiencia del acto por la propia administración cons-

52 Ley Federal núm. 9.784 de 1999: “Artículo 55. En decisión en la que se evidencie no haber lesión al interés público o perjudicar a terceros, los actos que presenten defectos sanables pueden ser convalidados por la administración". 
tituye, en sí misma, una manifestación de control interno, que debe ser ejecutado siempre que un acto administrativo pase a no estar de acuerdo, por ejemplo, con los criterios de economicidad y productividad anteriormente mencionados. Si entre los diversos medios admitidos por la ley el administrador optó por el menos idóneo al alcance del punto óptimo, es decir, a la consecución del resultado más provechoso y ventajoso a la administración, el acto debe ser corregido internamente.

En el caso de que la actividad administrativa no sea revisada mediante control interno - y se mantenga en el mundo jurídico - el acto ineficiente (y, por lo tanto, antijurídico), deberá ser entonces corregido por medio de los mecanismos de control externo, ejercido por el Poder Legislativo por medio de su atribución de fiscalización, o por el Poder Judicial, mediante el control jurisdiccional.

\section{Con relación a los terceros afectados: responsabilidad del Estado} por actuación ineficiente

Los terceros perjudicados por el comportamiento ineficiente del Estado, si atendidos los requisitos necesarios, serán titulares del derecho a indemnización de los daños ocasionados por la actividad administrativa contraria al deber de eficiencia. Se trata de una relevante consecuencia de la violación al principio de eficiencia.

El artículo 37, $\S 60$. de la Constitución brasileña, que traduce el fundamento normativo de la responsabilidad civil del Estado en Brasil, no hace distinción entre comportamientos omisivos y comisivos: "Las personas jurídicas de derecho público y las de derecho privado prestadoras de servicios públicos responderán por los daños que sus agentes, en esa calidad, causen a terceros, asegurado el derecho de regreso contra el responsable en los casos de dolo o culpa". De esta instrucción se infiere un régimen uniforme de responsabilización, bien sea para los excesos o para las inoperancias de la administración. Tal es la interpretación de Romeu Felipe Bacellar Filho, que en estudio específico sobre el tema afirma: "si la Constitución Federal, en su superior posición, adopta la responsabilización objetiva, no hay como desconsiderar el mandamiento constitucional, incluso en la hipótesis de omisión". ${ }^{33}$

53 Bacellar Filho, Romeu Felipe, "Responsabilidad civil del Estado por omisión", Revista Argentina del Régimen de la Administración Pública, Argentina, vol. 326, 2006, p. 52. 
El texto constitucional exige la comprobación de dolo o culpa solamente en el caso de la acción regresiva del Estado ante al agente. Pero en la relación víctima-Estado, la responsabilidad objetiva es la medida que se impone.

Por lo tanto, en el ordenamiento jurídico brasileño el Estado se encuentra sometido a una sistemática homogénea de responsabilización derivada del comportamiento ineficiente, sea comisiva (mal funcionamiento) $\mathrm{u}$ omisiva (no funciona o funciona tardíamente): la responsabilidad objetiva. Dicho esto, es esencial en este momento verificar cuáles son los elementos que componen ese mecanismo de apuración de la responsabilidad extraído del sistema jurídico.

Hay tres requisitos necesarios para que se pueda configurar la responsabilidad por la violación del principio de eficiencia: a) incumplimiento de un deber jurídico concreto de actuar (omisión) o cumplimiento precario (acción) por parte del Estado o de quien le represente; b) ocurrencia de daño al ciudadano; c) nexo de causalidad entre el comportamiento estatal y el perjuicio sufrido.

\section{A. Incumplimiento de un deber jurídico concreto de actuar (omisión) o cumplimiento precario (acción) por parte del Estado o de quien le represente}

Un comportamiento ineficiente podrá ser comisivo u omisivo. Si la acción practicada es diferente de aquella prevista legalmente, habrá entonces el incumplimiento comisivo de la norma, no omisivo. La acción ineficiente no implica la existencia de la necesaria inercia característica de la omisión. $\mathrm{Ni}$ todo acto ineficiente es realizado por omisión. Y tampoco toda abstención de cumplimiento del deber es caso de ineficiencia. ${ }^{54}$

Con relación a los daños causados por la acción, este primer elemento - a) el comportamiento ineficiente - restará configurado cuando el Estado (o quien le represente) deje de atender a alguno de los despliegues del principio de eficiencia administrativa. Tratándose de omisión, es necesario que haya el incumplimiento de un deber específico, concreto, impuesto por el ordenamiento jurídico al Estado.

${ }^{54}$ Gabardo, Emerson, "Responsabilidade objetiva do Estado em face dos princípios da eficiência e da boa-fé", en Ferraz, Luciano y Motta, Fabrício (orgs.), Direito público moderno, Brasil, Del Rey, 2003, pp. 284 y 285. 
La doctrina española comúnmente afirma que para configurarse una omisión jurídicamente relevante, son necesarios dos elementos: i) uno material, o sea la constatación, en el mundo de los hechos, de una situación de pasividad o inercia de la administración, y ii) uno formal, o sea la infracción de un deber legal o constitucional de actuar, que hace antijurídica la omisión material. ${ }^{55} \mathrm{Si}$ no hay deber legal o constitucional de actuar (elemento formal), no hay omisión y por consiguiente no hay responsabilidad. Esto ocurre no porque de la conducta omisiva no puedan surgir efectos jurídicos de forma directa, sino porque en este caso la omisión es irrelevante bajo el punto de vista del derecho.

Cabe señalar que no siempre la omisión se configurará como un incumplimiento del deber de impedir una acción externa. ${ }^{56}$ Como subraya Weida Zancaner: "puede la omisión llegar a ser causa eficiente del daño". ${ }^{77}$ Hay casos en que el deber de acción es distinto del deber de impedir un acto de tercero o factor exterior. Es el caso de la omisión del Estado en cumplir una orden constitucional específica, como la obligación de realizar la revisión general anual de los empleados públicos (artículo 37, X de la Constitución brasileña). ${ }^{58} \mathrm{El}$ propio incumplimiento del ente en promulgar la ley revisando la remuneración de los empleados públicos se configura como la causa dañina, ocasionadora de un perjuicio indemnizable. Lo mismo ocurre con relación al deber de prestación de servicios públicos para la realización del derecho fundamental a la educación, ${ }^{59}$ por ejemplo (artícu-

55 Gómez Puente, Marcos, La inactividad de la administración, 3a. ed., España, 2002, p. 62.

56 Bandeira de Mello, Celso Antônio, Curso de direito administrativo, 27a. ed., Brasil, Malheiros, 2010, p. 997.

57 Zancaner, Weida, "Da responsabilidade extracontratual da administração pública", Revista dos Tribunais, Brasil, 1981, p. 62.

58 Constitución de la República Federativa de Brasil (1988): “Artículo 37. La administración pública, directa, indirecta o institucional de cualquiera de los poderes de la Unión, de los estados, del Distrito Federal y de los municipios obedecerá a los principios de legalidad, impersonalidad, moralidad, y también a lo siguiente... X - la remuneración dos servidores públicos y el sueldo de que trata el $\S 40$. del artículo 39 solamente podrán ser fijados o alterados por ley específica, observada la iniciativa privativa en cada caso, asegurada la revisión general anual, siempre en la misma fecha y sin distinción de índices". Gabardo, Emerson, "Responsabilidade objetiva do...", cit., p. 280.

59 Sobre el tema del derecho fundamental a la educación en la Constitución brasileña, véase Wunder Hachem, Daniel y Abreu Kalil, Gilberto Alexandre de, "O direito fundamental social à educação e sua maximização por meio da função extrafiscal dos tributos: 
los 6o. y 205 de la Constitución brasileña): ${ }^{60}$ la ausencia de la prestación del servicio por inexistencia de vacante en escuela pública constituye, por sí misma, la omisión causante del daño. Por lo tanto, para configurarse una omisión apta a originar un daño indemnizable no es necesario que se trate del incumplimiento de un deber estatal de impedir un evento externo.

\section{B. Ocurrencia de daño al ciudadano}

Para que se configure el deber de indemnizar, es necesario que el ciudadano sufra un daño concreto, de naturaleza material o moral. En materia de responsabilidad pública por acción, es irrelevante la licitud o ilicitud de la conducta estatal. Lo que pasa es que cuando se trata de omisión, como dicho anteriormente, ella será jurídicamente relevante solamente en las hipótesis en que la inactividad estatal configure un incumplimiento de un deber jurídico. Por ello, tratándose de omisión, aunque no se exija la ocurrencia de negligencia, imprudencia o impericia, será esencial la antijuridicidad de la inercia para dar lugar a la responsabilidad. Sin embargo, la sola contrariedad de la omisión al derecho no es suficiente para originar el deber de indemnizar. Además de la ilicitud o inconstitucionalidad de la conducta, el ciudadano habrá de comprobar la existencia de un daño concreto, específico, por él sufrido.

\section{Nexo de causalidad entre el comportamiento estatal y el perjuicio sufrido}

Además de los dos elementos antes mencionados, es menester la comprobación de que el daño experimentado fue una consecuencia de la conducta estatal. Por ejemplo, la falencia de una empresa que había requerido la

o exemplo do Programa Universidade para Todos (Prouni)", A\&C-Revista de Direito Administrativo \& Constitucional, Brasil, vol. 16, núm. 66, 2016, pp. 153-177.

${ }^{60}$ Constitución de la República Federativa de Brasil de 1988: “Artículo 6o. Son derechos sociales la educación, la salud, la alimentación, el trabajo, la vivienda, el descanso, la seguridad, la jubilación, la protección de la maternidad y de la infancia, la asistencia a los desamparados, en la forma de esta Constitución". “Artículo 205. La educación, derecho de todos y deber del Estado y de la familia, será promovida e incentivada con la colaboración de la sociedad, visando al pleno desenvolvimiento de la persona, su preparo para el ejercicio de la ciudadanía y su calificación para el trabajo". 
renovación de una licencia ambiental para explorar una actividad económica, sin tener su pedido apreciado y deferido por la administración dentro del plazo legalmente establecido, puede ser demostrada como un efecto directo de la abstención estatal, cuando la imposibilidad de seguir explotando su actividad, originada por la no resolución de su requerimiento administrativo, impida el cumplimiento de sus obligaciones con creedores.

En este punto, tal vez, resida la principal causa de la disputa teórica respecto de la naturaleza objetiva o subjetiva de la responsabilidad civil del Estado: hay, muchas veces, una confusión de la doctrina entre dos categorías jurídicas distintas: el nexo de causalidad y la culpa. Cuando se dice, por ejemplo, que en razón del supuesto carácter subjetivo de la responsabilidad por omisión, el Estado no tiene el deber de indemnizar al ciudadano que sufrió un accidente causado por un evento irresistible de la naturaleza, pues aunque se haya omitido, él no tenía el deber de evitar el daño, lo que en verdad se está afirmando es que no había nexo causal entre la abstención y el perjuicio. La causa eficiente del daño fue el factor externo y no la omisión estatal, porque no existía el deber jurídico de evitarlo. La razón de la no configuración de responsabilidad en este caso no es la ausencia de culpa, sino la inexistencia de nexo de causalidad.

Hay que separarse, como en general se hace en el derecho penal, los planos de la antijuridicidad y de la culpabilidad. El primero se refiere a la contrariedad de la conducta al ordenamiento jurídico. El segundo consiste en la reprobabilidad del comportamiento, por exigirse conducta diversa. Tratándose de responsabilidad civil del Estado por omisión, es necesaria la ocurrencia de antijuridicidad — contraria al sistema normativo- pero es irrelevante jurídicamente la culpabilidad — existencia de comportamiento reprobable-.

\section{CONCLUSIONES}

De la investigación realizada, es posible sintetizar las siguientes conclusiones:

1. En el sistema jurídico brasileño, el principio de eficiencia administrativa no estaba previsto expresamente en la Constitución de 1988 y fue insertado diez años después por la Enmienda Constitucional núm. 19/1998, en un contexto de reforma estatal influenciado por el 
neoliberalismo, que tenía como uno de sus objetivos reducir el aparato del Estado y remplazar el modelo de administración burocrática por el gerencial. Sin embargo, el contenido jurídico de este principio no puede ser definido por la ideología subyacente al escenario político en el cual fue positivizado. Su carga normativa debe ser identificada a partir de una interpretación sistemática de la Constitución brasileña, que adopta un modelo de Estado social y democrático de derecho.

2. Desde la perspectiva jurídico-constitucional, el contenido normativo del principio de eficiencia administrativa puede ser definido como el deber impuesto por la Constitución a la administración pública de: a) ejercitar la potestad administrativa que le es jurídicamente conferida con la máxima celeridad, presteza, economicidad y productividad; b) actuando de modo a concretar fielmente la finalidad pública subyacente a las normas jurídicas a las cuales está sometida; c) utilizando los medios más adecuados al alcance óptimo de los objetivos estatuidos por el derecho positivo (interés público); $d$ ) confiriendo la máxima efectividad a los comandos que le son dirigidos por el ordenamiento jurídico, y e) siempre de acuerdo con los derechos fundamentales y con los demás principios y reglas que orientan la actividad administrativa.

3. Con relación al incumplimiento de los deberes originados del principio constitucional de eficiencia administrativa, hay por lo menos tres consecuencias jurídicas que derivan de su violación: a) con relación a los agentes públicos, la infracción de los comandos extraídos del deber de eficiencia podrá generar su responsabilización personal, en los ámbitos administrativo, civil y penal; b) con relación a la actividad practicada, su disconformidad con las exigencias producidas por el principio examinado, resulta en el sometimiento del acto (o procedimiento) al control interno o externo, que debe operarse con el objetivo de corregir la actuación administrativa ineficiente; c) respecto de los terceros alcanzados por los efectos de la actividad, los perjuicios experimentados en consecuencia de la actuación ofensiva al principio de eficiencia suscitará la responsabilidad civil del Estado, cuando estuvieren presentes los elementos configuradores del deber de reparar el daño. 
4. El sistema constitucional brasileño, cuando trata del régimen de responsabilidad patrimonial del Estado por daños ocasionados a terceros, no produce distinción entre comportamientos omisivos y comisivos, razón por la cual se puede afirmar que existe un régimen uniforme de responsabilización objetiva derivada del comportamiento ineficiente, sea comisivo (mal funcionamiento) $\mathrm{u}$ omisivo (no funciona o funciona tardíamente). Y eso porque el artículo 37, §6o., de la Constitución exige la comprobación de dolo o culpa solamente en el caso de acción regresiva del Estado ante al agente, mas no en la relación víctima-Estado. Por lo tanto, son tres los requisitos necesarios para la configuración de la responsabilidad del Estado por violación del principio de eficiencia: a) incumplimiento de un deber jurídico concreto de actuar (omisión) o cumplimiento precario (acción) por parte del Estado o de quien le represente; b) ocurrencia de daño al ciudadano, y c) nexo de causalidad entre el comportamiento estatal y el perjuicio sufrido.

\section{BIBLIOGRAFÍA}

Albert, Richard, "The Expressive Function of Constitutional Amendment Rules", Revista de Investigações Constitucionais, Brasil, vol. 2, núm. $1,2015$.

AlianaK, Raquel Cynthia, "Seguridad jurídica, buena fe y confianza legítima frente a actos estatales", Revista Eurolatinoamericana de Derecho Administrativo, Argentina, vol. 2, núm. 2, 2015.

Andreani, Antonio, Il principio costituzionale di buon andamento della publica amministrazione, Italia, CEDAM, 1979.

Antunes Rocha, Cármen Lúcia, Princípios constitucionais da administração pública, Brasil, Del Rey, 1994.

Bacellar Filho, Romeu Felipe, "A estabilidade do ato administrativo criador de direitos à luz dos princípios da moralidade, da segurança jurídica e da boa-fé", A\&C-Revista de Direito Administrativo \& Constitucional, Brasil, vol. 10, núm. 40, 2010.

Bacellar Filho, Romeu Felipe, "O direito fundamental à presunção de inocência no processo administrativo disciplinar", $A \& C$-Revista de Direito Administrativo \& Constitucional, Brasil, vol. 9, núm. 37, 2009. 
Bacellar Filho, Romeu Felipe, "O regime jurídico das organizações sociais e a sua contratação pelo poder público mediante dispensa de licitação", en Bacellar FILHO, Romeu Felipe, Reflexões sobre direito administrativo, Brasil, Editora Fórum, 2009.

Bacellar Filho, Romeu Felipe, Processo administrativo disciplinar, 3 a. ed., Brasil, Saraiva, 2011.

Bacellar Filho, Romeu Felipe, "Responsabilidad civil del Estado por omisión", Revista Argentina del Régimen de la Administración Pública, Argentina, vol. 326, 2006.

Bacellar Filho, Romeu Felipe y Wunder Hachem, Daniel, "A necessidade de defesa técnica no processo administrativo disciplinar e a inconstitucionalidade da Súmula Vinculante núm. 5 do STF”, $A \& C-R e$ vista de Direito Administrativo \& Constitucional, Brasil, vol. 10, núm. 39, 2010.

Balbín, Carlos Francisco, "Un derecho administrativo para la inclusión social", A\&C-Revista de Direito Administrativo \& Constitucional, Brasil, vol. 14, núm. 58, 2014.

Bandeira de Mello, Celso Antônio, Curso de direito administrativo, 27a. ed., Brasil, Malheiros, 2010.

Bandeira de Mello, Celso Antônio, Discricionariedade e controle jurisdiccional, 2a. ed., Brasil, Malheiros, 2003.

Bandeira de Mello, Celso Antônio, Grandes temas de direito administrativo, Brasil, Malheiros, 2009.

BERnARDI, Ovídio, "Responsabilidade dos prefeitos municipais: políticas, político-administrativas, civis e criminais", Revista dos Tribunais, Brasil, 1962.

Cassagne, Juan Carlos, "El nuevo constitucionalismo y las bases del orden jurídico", Revista de Investigações Constitucionais, Brasil, vol. 2, núm. 1, 2015.

Corvalán, Juan G., "Los ejes centrales de la división de poderes en el Estado constitucional de derecho", Revista de Investigações Constitucionais, Brasil, vol. 2, núm. 1, 2015.

FALzone, Guido, Il dovere di buona amministrazione, Italia, Giuffrè, 1953.

FInger, Ana Cláudia, "Serviço Público: Um Instrumento de Concretização de Direitos Fundamentais", A\&C-Revista de Direito Administrativo \& Constitucional, Brasil, vol. 3, núm. 12, 2003. 
FreITAS, Juarez, O controle dos atos administrativos e os princípios fundamentais, 2a. ed., Brasil, Malheiros, 1999.

Fuentetaja Pastor, Jesús Ángel, "El derecho a la buena administración en la Carta de los Derechos Fundamentales de la Unión Europea”, Revista de Derecho de la Unión Europea, España, núm. 15, 2008.

GABARDO, Emerson, Eficiência e legitimidade do Estado, Brasil, Manole, 2003.

GABARDO, Emerson, Interesse público e subsidiariedade, Brasil, Fórum, 2009.

GABARDO, Emerson, "Mecanismos de intervención del Estado en Brasil, postmodernidad y la cuestión de la subsidiariedad", Revista Eurolatinoamericana de Derecho Administrativo, Argentina, vol. 1, núm. 2, 2014.

Gabardo, Emerson, Princípio constitucional da eficiência administrativa, Brasil, Dialética, 2002.

GabARDO, Emerson, "Responsabilidade objetiva do Estado em face dos princípios da eficiência e da boa-fé", en Ferraz, Luciano y MotTA, Fabrício (orgs.), Direito público moderno, Brasil, Del Rey, 2003.

Galera Rodrigo, Susana, "El derecho a una buena administración", en Álvarez Conde, Enrique y Garrido Mayol, Vicente (dirs.), Comentarios a la Constitución Europea, España, libro II: Los derechos y libertades, 2004.

Galera Rodrigo, Susana, "The Right to a Fair Trial in the EU: Lights and Shadows", Revista de Investigações Constitucionais, Brasil, vol. 2, núm. 2, 2015.

Garrido Falla, Fernando, Tratado de derecho administrativo, 12a. ed., España, Tecnos, vol. II, 2006.

Gomes Canotilho, J. J., Direito constitucional e teoria da Constituição, 7a. ed., Portugal, 2003.

Gómez Puente, Marcos, La inactividad de la administración, 3a. ed., España, 2002.

GonzÁlez Alonso, Luis N., "Artículo 41: Derecho a una buena administración”, en Mangas Martín, Araceli (dir.) y González Alonso, Luis N. (coord.), Carta de los Derechos Fundamentales de la Unión Europea: comentario artículo por artículo, España, Fundación BBVA, 2008. 
Gordillo, Agustín, Tratado de derecho administrativo, 5a. ed., Argentina, Del Rey-Fundación de Derecho Administrativo, t. II: La defensa del usuario y del administrado, 2003.

HuAPaya TAPIA, Ramón A., "El derecho constitucional al debido procedimiento administrativo en la ley del procedimiento administrativo general de la República del Perú", Revista de Investigações Constitucionais, Brasil, vol. 2, núm. 1, 2015.

JorDÃo, Eduardo, "La dynamique de la déférence: création et évolution des modèles auto-restrictives de contrôle juridictionnel dans le droit comparé", Revista de Investigações Constitucionais, Brasil, vol. 2, núm. 3, 2015.

Sото Kloss, Eduardo, Derecho administrativo. Bases fundamentales, Chile, Jurídica de Chile, 1996, t. II: El principio de juridicidad.

LAUbADÈre, André de, Traité élémentaire de droit administratif, 3a. ed., Francia, LGDJ, 1963, t. I.

MeILÁN GiL, José Luis, "Intereses generales e interés público desde la perspectiva del derecho público español”, A\&C-Revista de Direito Administrativo \& Constitucional, Brasil, vol. 10, núm. 40, 2010.

MeILÁN GIL, José Luis, "Una construcción jurídica de la buena administración”, A\&C-Revista de Direito Administrativo \& Constitucional, Brasil, vol. 13, núm. 54, 2013.

Lopes MeIrelles, Hely, Direito administrativo brasileiro, 16a. ed., Brasil, Malheiros, 1991.

MoreIra Neto, Diogo de Figueiredo, Legitimidade e discricionariedade: novas reflexões sobre os limites e controle da discricionariedade, $2 \mathrm{a}$. ed., Brasil, Forense, 1991.

Muller Bitencourt, Caroline, "Sobre o possível controle judicial de políticas públicas: um olhar a partir do campo de conformação do legislador e do administrador", Revista Eurolatinoamericana de Derecho Administrativo, Argentina, vol. 2, núm. 2, 2015.

NogueIra, Paulo Lúcio, Administração e responsabilidade dos prefeitos e vereadores, Brasil, Sugestões Literárias, 1974.

Oliveira Moraes, Germana de, Controle jurisdicional da administração pública, Brasil, Dialética, 1999.

Parejo Alfonso, Luciano, Eficacia y administración. Tres estudios, España, INAP, 1995. 
Parejo Alfonso, Luciano, "La eficacia como principio jurídico de la actuación de la administración pública", Documentación Administrativa, España, núms. 218 y 219, 1989.

Pondé FonsecA, Juliana, “The Vanishing Boundaries between Technical and Political: Normativism and Pragmatism in the Brazilian Courts' Adjustment of Public Policies", Revista de Investigações Constitucionais, Brasil, vol. 2, núm. 3, 2015.

Ponce Solé, Juli, Deber de buena administración y derecho al procedimiento administrativo debido: las bases constitucionales del procedimiento administrativo y del ejercicio de la discrecionalidad, España, Lex Nova, 2001.

Rocha FrançA, Vladimir da, "Eficiência administrativa na Constituição Federal", Revista de Direito Administrativo, Brasil, núm. 220, 2000.

RodríGuEZ-Arana MuÑoz, Jaime, "Dimensiones del Estado social y derechos fundamentales sociales", Revista de Investigações Constitucionais, Brasil, vol. 2, núm. 2.

RodríGuez-Arana MuÑoz, Jaime, Direito fundamental à boa administração pública, trad. de Daniel Wunder Hachem, Brasil, Fórum, 2012.

RodríGuEZ-Arana MuÑoz, Jaime, "El derecho administrativo ante la crisis (el derecho administrativo social)", Revista Eurolatinoamericana de Derecho Administrativo, Argentina, vol. 2, núm. 2, 2015.

RodríGUEZ-Arana MuÑoz, Jaime, "La cláusula del Estado social de derecho y los derechos fundamentales sociales", Revista Eurolatinoamericana de Derecho Administrativo, Argentina, vol. 2, núm. 1, 2015.

RodríGuEZ-Arana MuÑoz, Jaime, "Sobre el derecho fundamental a la buena administración y la posición jurídica del ciudadano", $A \& C$ Revista de Direito Administrativo \& Constitucional, Brasil, vol. 12, núm. 47, 2012.

RoDríGUEZ-ARANA MUÑoz, Jaime, "El derecho fundamental a la buena administración en la Constitución española y en la Unión Europea", A\&C-Revista de Direito Administrativo \& Constitucional, Brasil, vol. 10, núm. 40, 2010.

Ruocco, Graciela, "La «buena administración» y el «interés general»”, A\&C-Revista de Direito Administrativo \& Constitucional, Brasil, vol. 12, núm. 49, 2012. 
SACRISTÁn, Estela, "Gestión eficiente y ética en la efectivización de los servicios públicos relativos a derechos sociales", Revista de Investigações Constitucionais, Brasil, vol. 3, núm. 1, 2016.

SCHIER, Adriana da Costa Ricardo, “Administração pública: apontamentos sobre os modelos de gestão e tendências atuais", en GUIMARÃES, Edgar (coord.), Cenários do direito administrativo: estudos em homenagem ao professor Romeu Felipe Bacellar Filho, Brasil, Fórum, 2004.

Schier, Adriana da Costa Ricardo, Regime jurídico do serviço público: garantia fundamental do cidadão e proibição de retrocesso social, tesis de doctorado en Derecho del Estado, Brasil, Universidade Federal do Paraná, 2009.

SöDERMAN, Jacob, "El derecho fundamental a la buena administración", Gaceta Jurídica de la Unión Europea y de la Competencia, España, núm. 214, 2001.

TomÁs MALlÉN, Beatriz, El derecho fundamental a una buena administración, España, INAP, 2004.

Wunder HaChem, Daniel, "A dupla noção jurídica de interesse público em direito administrativo", $A \& C$-Revista de Direito Administrativo \& Constitucional, Brasil, vol. 11, núm. 44, 2011.

Wunder Hachem, Daniel, "A noção constitucional de desenvolvimento para além do viés econômico: reflexos sobre algumas tendências do direito público brasileiro", A\&C-Revista de Direito Administrativo \& Constitucional, Brasil, vol. 13, núm. 53, 2013.

Wunder Hachem, Daniel, "Direito fundamental ao serviço público adequado e capacidade econômica do cidadão: repensando a universalidade do acesso à luz da igualdade material", $A \& C$-Revista de Direito Administrativo \& Constitucional, Brasil, vol. 14, núm. 55, 2014.

Wunder Hachem, Daniel, "Processos administrativos reivindicatórios de direitos sociais: dever de decidir em prazo razoável vs. silêncio administrativo", A\&C-Revista de Direito Administrativo \& Constitucional, Brasil, vol. 14, núm. 56, 2014.

Wunder Hachem, Daniel y Abreu Kalil, Gilberto Alexandre de, "O direito fundamental social à educação e sua maximização por meio da função extrafiscal dos tributos: o exemplo do Programa Universidade para Todos (Prouni)", A\&C-Revista de Direito Administrativo \& Constitucional, Brasil, vol. 16, núm. 66, 2016. 
ZANCANER, Weida, "Da responsabilidade extracontratual da administração pública", Revista dos Tribunais, Brasil, 1981.

Zanella di Pietro, Maria Sylvia, Discricionariedade administrativa na Constituição de 1988, Brasil, Atlas, 1991.

Zanella di Pietro, Maria Sylvia, Parcerias na administração pública, 7a. ed., Brasil, Atlas, 2009.

Fecha de recepción: 21 de febrero de 2017.

Fecha de dictamen: 2 de diciembre de 2017. 